\title{
PELATIHAN IMPLEMENTASI BUDAYA MUTU BERBASIS KEARIFAN LOKAL DI SDN GUGUS I PEMENANG LOMBOK UTARA
}

\author{
Asrin'1), Linda Feni Haryati1), Muhammad Syazali1), Umar'1), Lalu Wira Zain Amrullah'1) \\ 1)Program Studi PGSD, FKIP, Universitas Mataram, Mataram, NTB, Indonesia \\ Corresponding author: Umar \\ E-mail : umarelmubaraq90@unram.ac.id
}

Diterima 24 November 2021, Direvisi 27 November 2021, Disetujui 27 November 2021

\begin{abstract}
ABSTRAK
Budaya mutu merupakan seperangkat nilai, norma serta keyakinan yang termanifestasi dalam aktivitas, perilaku, dan simbol di sekolah agar mencapai keunggulan yang diinginkan dan diharapkan sehingga tercapai akuntabilitas sekolah. Berbagai terobosan baru harus terus dilakukan sebagai upaya meningkatkan pemahaman dasar tentang budaya mutu sehingga pelayanan di bidang pendidikan dapat dilakukan secara terorganisir dan professional di lingkungan sekolah. Dalam rangka membangun budaya mutu pada level kelembagaan sangat membutuhkan keseriusan dari semua elemen sekolah. Salah satu caranya adalah dengan mengikuti pelatihan yang berkaitan dengan budaya mutu. Sehubungan dengan itu maka tim pengabdian masyarakat dari Program Studi PGSD FKIP Universitas Mataram melakukan pelatihan implementasi budaya mutu berbasis kearifan lokal di SDN Gugus I Pemenang. Tujuannya adalah setelah mengikuti kegiatan ini, guru dan kepala sekolah dapat membangun budaya mutu di lingkungan sekolah masing-masing agar dapat lebih baik dari sebelumnya. Kegiatan pengabdian kepada masyarakat ini terdiri dari tiga tahapan yaitu tahap persiapan, tahap pelaksanaan, dan tahap evaluasi. Kegiatan ini diikuti oleh perwakilan guru dan kepala sekolah dari Gugus 1 Pemenang yang berjumlah 20 peserta. Pelaksanaan kegiatan pelatihan dilakukan secara offline yaitu di Sekolah SDN 3 Pemenang. Kegiatan dilakukan dengan mengikuti anjuran protokol kesehatan covid 19. Kegiatan berjalan dengan sangat lancar. Respons peserta terhadap pelaksanaan kegiatan sangat baik.
\end{abstract}

Kata kunci: pengabdian masyarakat; budaya mutu; kearifan lokal.

\begin{abstract}
Quality culture is a set of values, norms, and beliefs that are manifested in activities, behaviors, and symbols in schools to achieve the desired and expected excellence so that school accountability is achieved. Various breakthroughs must continue to be made as an effort to improve the basic understanding of a quality culture so that services in the field of education can be carried out in an organized and professional manner in the school environment. Building a quality culture at the institutional level really requires seriousness from all elements of the school. One way is to take part in training related to quality culture. In this regard, the community service team from the PGSD FKIP Study Program at the University of Mataram conducted training on the implementation of a quality culture based on local wisdom at SDN Cluster I Pemenang. The goal is that after participating in this activity, teachers and principals can build a quality culture in their respective schools so that they can be better than before. This community service activity consists of three stages, namely the preparation stage, the implementation stage, and evaluation stage. This activity was attended by representatives of teachers and school principals from Cluster 1 Pemenang, totaling 20 participants. The implementation of training activities is carried out offline, namely at SDN 3 Pemenang School. The activity was carried out by following the recommendations for the Covid 19 health protocol. The activity went very smoothly. The response of the participants to the implementation of the activity was very good.
\end{abstract}

Keywords: community dedication; quality culture; local wisdom.

\section{PENDAHULUAN}

Mutu pendidikan hingga saat ini masih menjadi topik pembicaraan di seputar dunia pendidikan. Hal ini disebabkan karena mutu pendidikan memiliki persoalan yang sangat kompleks. Oleh sebab itu maka upaya meningkatkan mutu pendidikan menjadi suatu kewajiban yang harus dilakukan secara bersama dan konsisten oleh semua komponen pendidikan (Midun, 2017). Budaya mutu merupakan seperangkat nilai, norma serta keyakinan yang termanifestasi dalam aktivitas, 
perilaku, dan simbol di sekolah agar mencapai keunggulan yang diinginkan dan diharapkan sehingga tercapai akuntabilitas sekolah (Rahmat, 2020). Hal ini sejalan dengan pendapat (Asrin, 2014) bahwa budaya mutu di satuan pendidikan mencakup simbol, aktivitas, dan nilai yang menjadi komitmen bersama oleh setiap elemen dalam upaya membangun mutu sekolah. Terobosan baru terus dilakukan sebagai upaya meningkatkan pemahaman dasar tentang budaya mutu sehingga pelayanan di bidang pendidikan dapat dilakukan secara terorganisir dan professional. Untuk menjawab berbagai tuntutan dari berbagai pihak seperti orang tua, masyarakat, serta stakeholder terhadap peningkatan mutu pendidikan maka sekolah diharapkan mampu menciptakan tradisi mutu yang tinggi serta berkelanjutan.

Peningkatkan mutu menjadi bagian penting pada sistem manajemen sekolah dan membutuhkan upaya konkrit yang harus dilakukan di sekolah. Hal ini karena dalam dalam mengelola sekolah sebagai upaya meningkatkan mutu pendidikan sekolah sangat diperlukan gaya kepemimpinan kepala sekolah yang baik (Said, 2018). Pada konteks ini, kepala sekolah sebagai pemimpin perlu menjadi garda terdepan dengan menjadikan budaya mutu sebagai mental map yang mencakup nilai, aktivitas dan strategi bagi setiap elemen sekolah dalam rangka memberikan jasa pelayanan pendidikan untuk meningkatkan mutu secara maksimal. Selain peran penting kepala sekolah, mutu pendidikan sangat dipengaruhi oleh kualitas kerja guru. Hal ini karena secara teknis guru menjadi komponen yang paling penting dalam penyelenggaraan pendidikan di sekolah. Menurut (Mashudi, 2021) semua sumber daya seperti sarana dan prasarana, media, perencanaan pembelajaran, maupun dukungan dana pendidikan yang besar tidak berdampak signifikan dalam meningkatkan mutu pendidikan jika guru tidak mempunyai kecakapan yang baik dalam manajemen pembelajaran yang efektif. Sehubungan dengan itu maka meningkatkan wawasan dan pengetahuan guru menjadi suatu keharusan demi terciptanya mutu pendidikan yang baik di lingkungan sekolah. Namun pada tataran implementasinya, tidak semua sekolah mampu meningkatkan mutunya secara maksimal. Berdasarkan hasil wawancara terhadap beberapa guru dan kepala sekolah di Gugus I Pemenang Kabupaten Lombok Utara, mereka masih kesulitan dalam menerapkan budaya mutu sebagai bagian dari manajemen sekolah. Pandemi Covid-19 yang mengurangi interaksi secara langsung tiap elemen sekolah menjadi tantangan tambahan. Masalah-masalah ini mengindikasikan perlu adanya intervensi dalam rangka membantu pihak sekolah.

Untuk itu pengembangan budaya mutu menjadi kebutuhan bagi keberlangsunagan mutu pendidikan di sekolah. Peningkatan budaya mutu berbasis kearifan lokal menjadi kebutuhan mutlak sekolah dalam ragka meningkatkan keunggulan dan daya saing sekolah. Selain itu juga, pendidikan yang berkualitas dapat tercipta dari mutu sekolah tersebut (Amin \& Siswanto, 2018). Lebih lanjut menurut (Anwar, 2014) dalam rangka meningkatkan budaya mutu pada level kelembagaan sangat membutuhkan keseriusan dari semua elemen sekolah. salah satu caranya adalah dengan mengikuti pelatihan yang dikuti baik oleh administrator, guru dan kepala sekolah. Berdasarkan hal tersebut kami bermaksud untuk melaksanakan pengabdian dengan mengangkat judul "Pelatihan Implementasi Budaya Mutu Berbasis Kearifan Lokal Di SDN Gugus I Pemenang". Pengabdian kepada masyarakat ini diharapkan dapat memberikan solusi terhadap masih rendahnya budaya mutu di sekolah - sekolah khususnya SDN di Gugus 1 Pemenang Kabupetan Lombok Utara. Pengabdian kepada masyarakat dalam bentuk pelatihan ini akan sangat berguna untuk kepala sekolah dan guru untuk meningkatkan pemahaman dan keterampilan dalam mengembangkan budaya mutu sekolah berbasis kearifan lokal.

\section{METODE}

Kegiatan pengabdian masyarakat ini dilakukan oleh tim dosen dari program studi PGSD Universitas Mataram. Kegiatan ini dilaksanakan secara offline di Sekolah SDN 3 Pemenang. Peserta kegiatan pengabdian merupakan guru dan kepala sekolah di gugus 1 Pemenang Kabupaten Lombok Utara berjumlah 20 orang. Jumlah peserta tersebut merupakan perwakilan dari seluruh guru dan kepala sekolah di Gugus 1 Pemenang. Hal ini disebabkan karena memperhatikan kondisi ruangan tempat pelatihan yang hanya cukup memuat 20 peserta. Kegiatan pelatihan guru dan kepala sekolah dilakukan sesuai protokol Kesehatan covid 19 dengan pemberlakuan jaga jarak antar peserta. Tahapan kegiatan pengabdian ini dibagi ke dalam tiga tahap kegiatan. Tahap pertama adalah tahap persiapan. Pada tahap ini tim dosen melakukan diskusi dengan pihak sekolah untuk menemukan persoalan dan memetakan masalah yang terjadi di lingkungan sekolah. Selain itu pada tahap ini juga tim dosen melakukan sosialisasi terkait rencana kegiatan yang akan dilaksanakan kepada guru, kepala 
sekolah, dan Kepala UPTD Dikbudpora Kecematan Pemenang. Tahap kedua adalah tahap pelaksanaan kegiatan pelatihan. Pada tahap ini guru dan kepala sekolah akan diberikan materi tentang implementasi budaya mutu berbasis kearifan lokal, dan literasi, numerasi, dan literasi digital. Pemberian materi ini dimaksudkan untuk menjawab persoalan yang terjadi di lingkungan sekolah. Hal ini sesuai dengan analisis kebutuhan yang dilakukan oleh tim dosen berdasarkan riset awal. Tahap ketiga adalah tahap evaluasi. Tahap ini dilaksanakan setelah kegiatan pelatihan selesai. Evaluasi dilakukan dengan cara pemberikan angket respons. Tujuannya adalah untuk mengukur respons guru dan kepala sekolah terhadap kegiatan yang sudah berlangsung.

\section{HASIL DAN PEMBAHASAN \\ Tahap Persiapan}

Pada tahap ini tim dosen melakukan kunjungan ke sekolah yang akan dijadikan tempat pelatihan dalam rangka pengabdian kepada masyarakat. Pada tahap ini tim dosen melakukan diskusi dengan guru dan kepala sekolah untuk menggali informasi tentang kendala, hambatan, dan masalah yang sering terjadi di lingkungan sekolah.

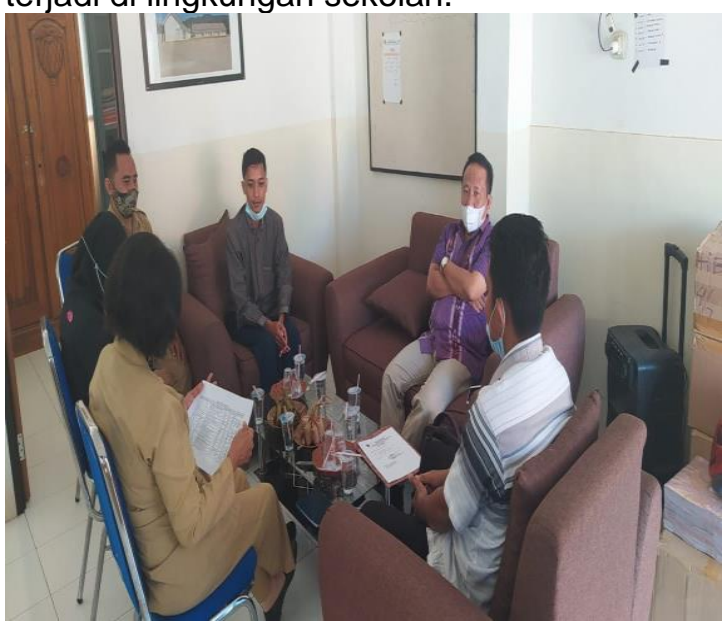

Gambar 1. Dokumentasi diskusi dengan guru dan kepala sekolah.

Pada tahap persiapan ini dilakukan riset awal. Riset awal ini sangat penting dilakukan agar tim pengabdian dapat memetakan masalah yang sebenarnya. harapannya persoalan dan permasalahan tersebut dapat diuraikan dan dicarikan alternatif solusi melalui kegiatan pengabdian yang dilakukan oleh tim dosen. Hasil diskusi tim pengabdian dengan guru dan kepala sekolah menemukan suatu kesimpulan bahwa guru dan kepala sekolah sangat membutuhkan pemahaman yang baik tentang bagaimana menerapkan budaya mutu berbasis kearifan lokal di lingkungan sekolah.
Sehubungan dengan itu, maka kegiatan pelatihan implementasi budaya mutu dianggap penting untuk dilakukan.

Selain itu pada tahap ini juga tim dosen melakukan sosialisasi kepada guru, dan kepala sekolah tentang rencana kegiatan pelatihan yang dilakukan oleh tim dosen PGSD Universitas Mataram. Pada tahap sosialisasi ini tim dosen mengundang secara resmi perwakilan guru dan kepala sekolah SDN yang tersebar di gugus 1 Pemenang. Selain guru dan kepala sekolah, tim pengabdian juga mengundang Ketua UPTD Dikbudpora Kecematan Pemenang. Hal ini dimaksudkan agar kegiatan diketahui dan mendapat izin dari stakeholder sekaligus dapat membuka dengan resmi ketika kegiatan berlangsung. Selain itu pada tahap ini juga tim pengabdian memastikan kesiapan pihak sekolah SDN 3 Pemenang untuk dijadikan sekolah tersebut sebagai tempat pelaksanaan kegiatan. Hal ini disambut baik oleh Kepala Sekolah SDN 3 Pemenang dengan mengizinkan sekolah tersebut dijadikan tempat pelatihan.

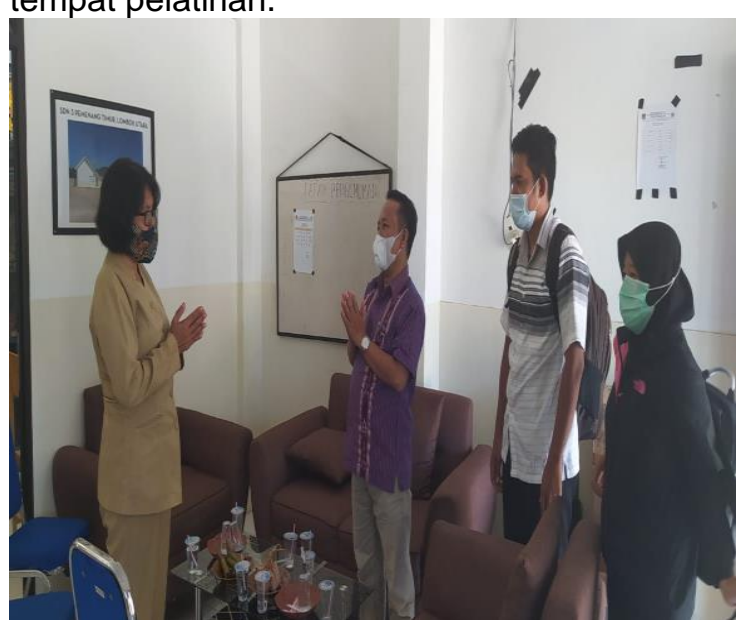

Gambar 2. Dokumentasi Bersama Kepala Sekolah SDN 3 Pemenang

\section{Tahap Pelaksanaan}

Kegiatan pelatihan implementasi budaya mutu berbasis kearifan lokal dilaksanakan sesuai rencana, yaitu pada hari sabtu tanggal 04 september 2021. Kegiatan dilaksanakan di Sekolah SDN 3 Pemenang. Kegiatan dimulai sesuai waktu yang sudah direncanakan yakni pukul 09.00 Wita dan selesai pukul 12.30 Wita. Kegiatan dihadiri oleh 20 peserta yang terdiri dari guru dan kepala sekolah. Kegiatan dimulai dengan pembukaan oleh Ibu Linda Feni Haryati selaku MC. Selanjutnya diikuti dengan pemberian kata sambutan oleh Bapak Dr. Asrin, M.Pd. selaku ketua tim pengabdian masyarakat. Setelah itu, kata sambutan juga disampaikan oleh lbu $\mathrm{Ni}$ Wayan Adeg, S.Pd. selaku kepala sekolah SDN 3 Pemenang yang dijadikan tempat 
pelaksanaan kegiatan. Kata sambutan terakhir sekaligus membuka secara resmi kegiatan pelatihan oleh Bapak Amanah, S.Pd. selaku Kepala UPTD Dikbudpora Kecematan Pemenang. Selanjutnya acara pembukaan ditutup dengan pembacaan doa oleh salah satu guru agama di sekolah SDN 3 Pemenang.

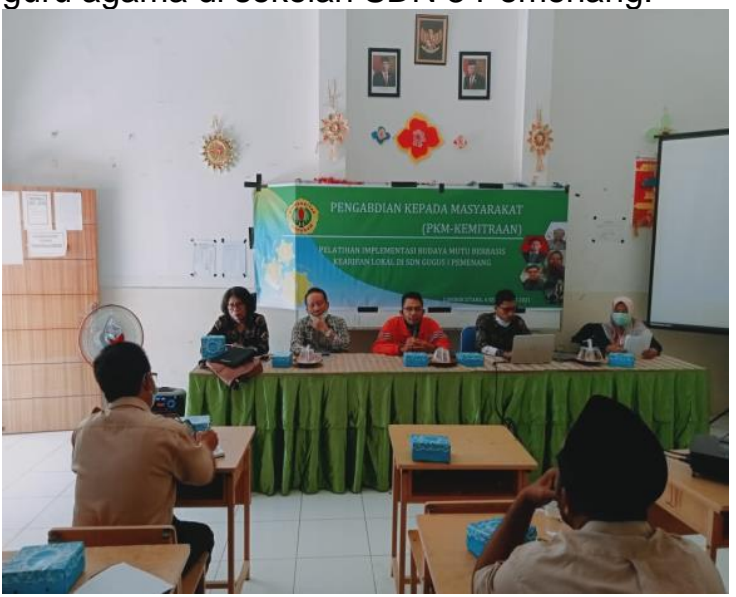

Gambar 3. Dokumentasi Pembukaan kegiatan pelatihan

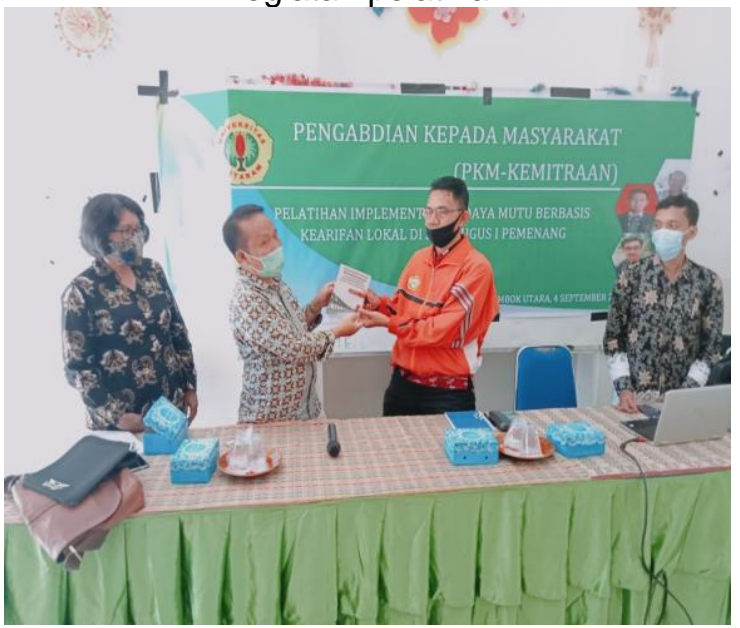

Gambar 4. Dokumentasi penyerahan buku oleh ketua tim pengabdian kepada Kepala UPTD Dikbudpora Kecematan Pemenang

Setelah acara pembukaan berakhir, kegiatan dilanjutkan pada kegiatan inti yaitu pemberian materi. Materi pada kegiatan terdiri dari dua topik. Topik pertama tentang implementasi budaya mutu berbasis kearifan lokal. Tujuannya adalah untuk memberi pemahaman yang baik tentang cara mengimplementasikan budaya mutu di lingkungan sekolah berbasis kearifan lokal. Hal ini sesuai dengan pernyataan (Suyitno, 2012) bahwa dalam upaya menumbuhkan budaya mutu serta pendidikan karakter di sekolah perlu disesuaikan dengan kearifan lokal di daerah tersebut.

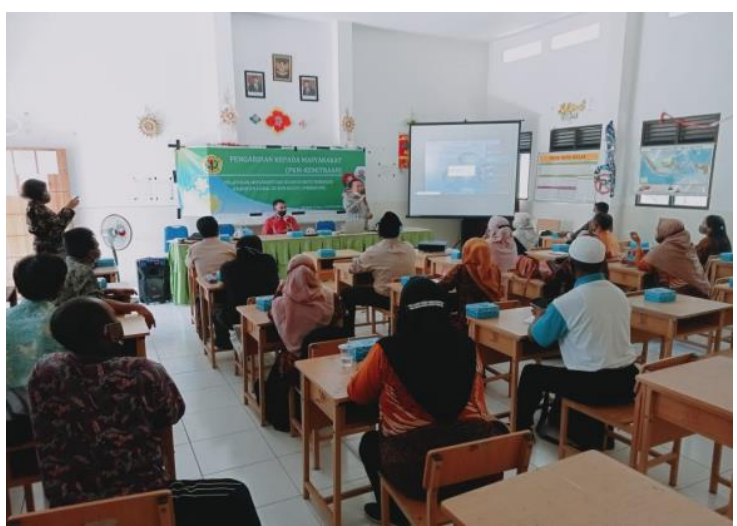

Gambar 5. Dokumentasi pemberian Materi Implementasi budaya mutu

Topik kedua adalah literasi digital dan pendidikan karakter. Pemberian materi tersebut untuk menjawab persoalan yang terjadi di lingkungan sekolah. Karakter yang baik sangat penting ditumbuhkan kepada peserta didik dari kecil khususnya di lingkungan sekolah dasar. Hal ini dapat ditanamkan oleh guru melalui proses pembelajaran di kelas. Hal ini sesuai dengan pendapat (Hendriana \& Jacobus, 2017) bahwa dengan memiliki karakter yang baik siswa memiliki sikap kepedualian yang tinggi, mandiri, dan bertanggung jawab. Selain itu juga pemberian materi ini menjawab kebutuhan guru dan kepala sekolah tentang pentingnya pemahaman dan pemanfaat literasi digital dalam menjawab tantangan pembelajaran di era pandemi covid 19. Dari hasil wawancara dengan guru dan kepala sekolah bahwa salah satu kendala yang dialami saat guru selama pandemi covid 19 adalah lemahnya kemampuan guru melakukan pembelajaran berbasis digital. Hal ini sesuai dengan temuan hasil penelitian (Diputra et al., 2020) bahwa banyak guru di sekolah dasar tidak melek digital. Sehubungan dengan itu maka sangat penting melatih guru agar melek digital. Hal ini sesuai dengan hasil penelitian (Dinata, 2021) bahwa keberhasilan pelaksanaan pembelajaran di masa pandemi covid 19 sangat dipengaruhi oleh kemampuan literasi digital pendidik. Hal ini karena tuntutan pembelajaran harus dilakukan secara online. Sejalan dengan itu, (Lisum \& Ratnauli Sianturi, 2020) mengatakan bahwa dengan memanfaatkan media online dalam pembelajaran dapat meningkatkan motivasi belajar peserta didik. Oleh sebab itu mau tidak mau sebagai pendidik harus dapat beradaptasi dengan perkembangan teknologi yang dapat menunjang keberhasilan dalam proses pembelajaran. 


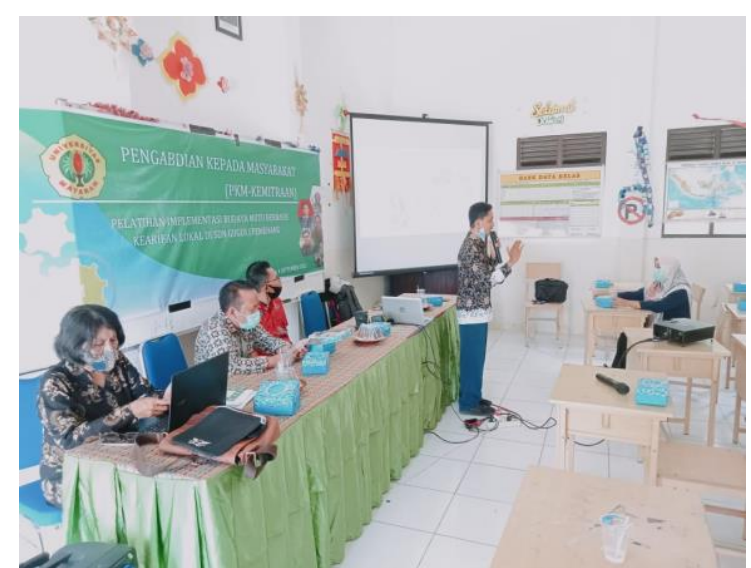

Gambar 6. Dokumentasi pemberian materi literasi digital dan pendidikan karakter.

Kegiatan dimulai dengan pemaparan materi oleh narasumber dan dilanjutkan dengan sesi diskusi. Pemaparan materi berjalan dengan lancar. Peserta diizinkan bertanya setelah pemaparan materi oleh narasumber. Proses diskusi berjalan sangat baik. terlihat peserta sangat aktif untuk bertanya. Setelah seluruh rangkaian kegiatan berakhir, acara diakhiri dengan kegiatan foto bersama.

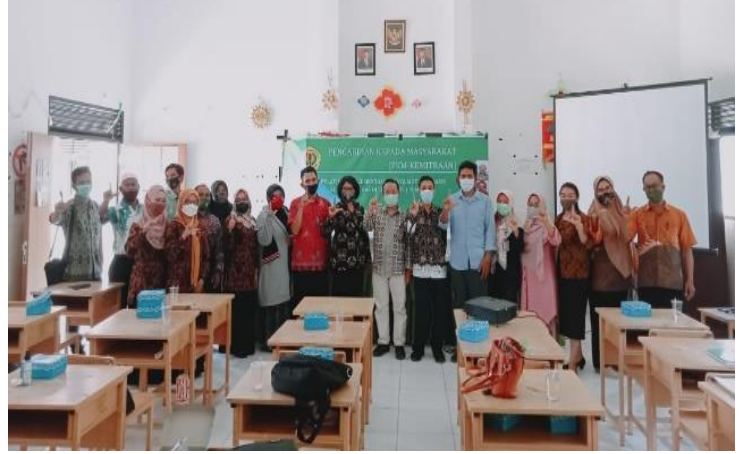

Gambar 7. Dokumentasi foto Bersama setelah kegiatan berakhir.

\section{Tahap Evaluasi}

Kegiatan monitoring dan evaluasi dimaksudkan untuk mengukur respons peserta terhadap pelaksanaan kegiatan. Untuk mengukur respons peserta menggunakan angket respons. Angket respons dibagikan ke peserta kegiatan setelah kegiatan berakhir. Hasil respons peserta terhadap pelaksanaan kegiatan adalah sebagai berikut: 1) Presentase jumlah peserta yang menyukai pelaksanaan kegiatan pelatihan adalah $100 \%$; 2) Presentase jumlah peserta yang merasakan dampak manfaat setelah mengikuti pelatihan adalah $96 \%$. 3) Presentase jumlah peserta yang menginginkan adanya pelatihan serupa di waktu yang akan datang yaitu 100\%. 4)
Presentase jumlah peserta yang bersedia mengikuti lagi jika ada kegiatan serupa di waktu yang akan datang adalah $100 \%$. Dari analisis angket respons di atas dapat disimpulkan bahwa, kegiatan pelatihan implementasi budaya mutu berbasis kearifan lokal mendapat respons yang positif dari peserta.

\section{SIMPULAN DAN SARAN}

Berdasarkan hasil dan pembahasan kegiatan di atas, dapat disimpulkan beberapa hal sebagai berikut: 1) Kegiatan pelatihan implementasi budaya mutu berbasis kearifan lokal yang sudah dilaksanakan di SDN Gugus 1 Pemenang berjalan dengan sangat baik dan lancer; 2) Hasil angket respons peserta kegiatan menunjukan bahwa peserta sangat senang terhadap pelaksanaan kegiatan tersebut. Menurut peserta kegiatan seperti dapat diulangi di waktu yang akan datang karena dinilai sangat bermanfaat.

Adapun saran kami kepada pembaca adalah mari kita sama-sama berusaha dan berupaya membangun budaya mutu di lingkungan kerja kita masing-masing. Selanjutnya, bagi yang ingin melakukan kegiatan serupa dapat meniru dan mengembangkan model pelatihan ini, sebagai upaya kita Bersama dalam membangun budaya mutu pendidikan.

\section{UCAPAN TERIMAKASIH}

Ucapan terima kasih kami ucapkan pertama kepada Kampus Universitas Mataram yang mendukung secara penuh atas terselenggaranya kegiatan pengabdian ini mulai dari pemberian izin dan alokasi dana sehingga kegiatan pengabdian ini berjalan dengan sangat lancer. Ucapan terima kasih kedua kami ucapakan kepada Dinas Pendidikan Lombok Utara dalam hal ini diwakili oleh Kepala UPTD Disbudpora Kecematan Pemenang yang sudah bersedia mengizinkan serta membuka dengan resmi kegiatan pengabdian ini. Selanjutnya ucapan terima kasih kami kepada Kepala Sekolah SDN 3 Pemenang karena telah menyediakan tempat dan fasilitas sehingga kegiatan pengabdian terselenggara dengan sangat baik.

\section{DAFTAR RUJUKAN}

Amin, N., \& Siswanto, F. (2018). Budaya Pendidikan, Budaya Organisasi Dan Budaya Mutu Lembaga Pendidikan Islam. Al-Tanzim Jurnal Manajemen Pendidikan Islam, 2(1), 94-106.

Anwar, S. (2014). Pengembangan Budaya Mutu Dalam Meningkatkan Kualitas Madrasah Di Madrasah Ibtidaiyyah Negeri Kota Bandar Lampung. ANALISIS: Jurnal Studi Keislaman, 14(2), 455-490. 
Dinata, K. B. (2021). Literasi Digital Dalam Pembelajaran Daring. Jurnal Eksponen, 11(1), 21-27.

Diputra, K. S., Tristiantari, N. K. D., \& Jayanta, I. N. L. (2020). Gerakan Literasi Digital Bagi Guru-Guru Sekolah Dasar. JCES (Journal of Character Education Society), 3(1), 118-128. http://journal.ummat.ac.id/index.php/JCE $\mathrm{S}$

Hendriana, E. C., \& Jacobus, A. (2017). Implementasi Pendidikan Karakter Di Sekolah Melalui Kegiatan Pembiasaan Dan Keteladanan. Tarbawi: Jurnal Keilmuan Manajemen Pendidikan, 3(02), 249.

https://doi.org/10.32678/tarbawi.v3i02.19 52

Lisum, K., \& Ratnauli Sianturi, S. (2020). Pelatihan E-Learning Untuk Menguatkan Peran Dosen Dalam Meningkatkan Motivasi Belajar Mahasiswa Keperawatan. SELAPARANG Jurnal Pengabdian Masyarakat Berkemajuan, 4(1), 241. https://doi.org/10.31764/jpmb.v4i1.2418

Mashudi, I. (2021). Dampak Komitmen dan Budaya Mutu Terhadap Kinerja Guru. Ideas Publishing.

Midun, H. (2017). Membangun Budaya Mutu dan Unggul di Sekolah. Jurnal Pendidikan Dan Kebudayaan Missio, 9(1), 50-59.

Rahmat, A. (2020). Kepemimpinan Pendidikan. Zahir Publishing.

Said, A. (2018). Kepemimpinan Kepala Sekolah Dalam Melestarikan Budaya Mutu Sekolah. EVALUASI, 2(1), 257-273.

Suyitno, I. (2012). Pengembangan Pendidikan Karakter Dan Budaya Bangsa Berwawasan Kearifan Lokal. Jurnal Pendidikan Karakter, 2(1), 1-13. https://doi.org/10.21831/jpk.v0i1.1307 